\title{
Model Evaluasi Reaction Level dari Kickpatrick Penyelenggaraan Pendidikan dan Pelatihan Kepemimpinan Tingkat III Angkatan II Provinsi Gorontalo
}

\author{
Thamrin A Kum \\ Widyaiswara Badan Diklat Provinsi Gorontalo \\ Gorontalo,Indonesia \\ Email: kumthamrin@yahoo.com
}

\begin{abstract}
As a stage in the management of Education and Training programs, the role of evaluation is crucial because evaluation becomes a tool for leaders whether the Training has reached the goal or not.Evaluation of Education and Training The Employees model reaction level from Kickpatrick is a very effective evaluation model of the effectiveness education and training program. This evaluation aims to measure reactions to training programs. The type of research used is qualitative decriptive with technical data analysis using weighting formula from Kickpatric. The $r$ esults showed that 1) Participants who provided positive training for higher training, 2) Participants who showed positive responses during the training, 3). I accommodation (area and facilities), 4) No participants showed any adverse reaction to the training
\end{abstract}

Keyword: Evaluation,; Model Reaction Rate; Kicpatrick

\begin{abstract}
Abstrak
Sebagai suatu tahapan dalam pengelolaan program Diklat, peran evaluasi amat menentukan karena evaluasi menjadi alat bagi pemimpin apakah Diklat itu sudah mencapai tujuan atau tidak. Evaluasi Pendidikan dan Pelatihan Aparatur model reaction level dari Kickpatrick adalah model evaluasi yang berfokus pada persepsi peserta terhadap program Pendidikan dan Pelatihan beserta tingkat efektifitasnya. Evaluasi ini bertujuan untuk mengukur reaksi peserta terhadap program pelatihan. Jenis penelitian yang digunakan adalah dekriptif kualitatif dengan tehnis analisis data menggunakan rumus pembobotan dari Kickpatric. Hasil penelitian menunjukan bahwa 1) Peserta menunjukkan reaksi positif yang tinggi terhadap pelatihan berkaitan dengan sebagian besar komponen pelatihan, 2) Peserta menunjukkan reaksi yang positif karena menyadari memperoleh masukan yang berguna selama pelatihan, 3) Peserta menunjukkan reaksi yang lebih baik terhadap pelatihan meliputi komponen asrama/penginapan (luas dan fasilitasnya), 4) Tidak ada peserta yang menunjukkan reaksi kurang baik terhadap pelatihan
\end{abstract}

Kata Kunci : Evaluasi; Model Reaction Level; Kicpatrick

Link DOI : http://dx.doi.org/10.31314/pjia.7.1.63-69.2018

Copyright @ 2018, Publik : (Jurnal Ilmu Administrasi), ISSN: 2301-573X (Print), ISSN: 2581-2084 (Online) 


\section{PENDAHULUAN}

Sumber daya manusia memainkan peranan yang penting dan strategis dalam mewujudkan tujuan pembangunan nasional. Kelemahan pada sumber daya manusia akan mempengaruhi upaya mewujudkan tujuan pembangunan nasional terancam tidak berhasil. Untuk menghindari kondisi yang tidak diinginkan ini maka mutlak diperlukan memanage sumber daya manusia aparatur pemerintah (Pegawai Negri Sipil) secara efektif.

Ruang lingkup manajemen SDM aparatur dapat berupa sistem penentuan kebutuhan, pengadaan atau rekruitmen, penempatan, pengembangan kapasitas, penilaian kinerja, promosi, kompensasi, disiplin dan terminasi atau pemberhentian. (Azis Sanapiah, 2008).

Kondisi saat ini menunjukkan bahwa kualitas aparatur yang ada masih perlu ditingkatkan. Potret aparatur saat ini sebagian masih menunjukan profesionalisme rendah. Banyaknya praktek KKN yang melibatkan aparatur, tingkat gaji yang dirasakan belum memadai, pemberian pelayanan masyarakat yang berbelilt-belit, tidak disiplin, kurang kreatif dan inovatif, serta masih banyak lagi potret negatif lainnya. Kondisi seperti ini memberikan dorongan kepada kita untuk berkomitmen melakukan perubahan SDM aparatur. Perubahan SDM aparatur dapat dilakukan dengan memberikan kesempatan kepada aparatur untuk meningkatkan kompotensinya melalui program Pendidikan dan Pelatihan (Diklat), hal ini sebagaiamana pendapat Prof. Azis Sanapiah (2008) bahwa upaya peningkatan kompotensi Pegawai Negeri Sipil (PNS) dapat dilakukan melalui Pendidikan dan Pelatihan dan Non Pendidikan dan Pelatihan.

Pendidikan dan Pelatihan (Diklat) aparatur pemerintah merupakan bagian integral dari Pendidika Nasional. UndangUndang Nomor 20 tahun 2003 tentang sistem Pendidikan Nasional (sisdiknas) Bab II pasal 3 menegaskan bahwa pendidikan nasional berfungsi mengembangkan kemampuan dan membentuk watak serta peradaban bangsa yang bermartabat dalam rangka mencerdaskan kehidupan bangsa, bertujuan untuk berkembangnya potensi peserta didik agar menjadi manusia yang beriman, dan bertaqwa kepada Tuhan yang Maha Esa, berakhlak mulia, sehat, berilmu, cakap kreatif, mandiri dan menjadi warga negara yang demokratis serta bertanggungjawab.

Lembaga Administrasi Negara Republik Indonesia (LAN-RI) melakukan berbagai upaya untuk menjadikan lembaga Diklat yang berkualitas, antara lain dengan menerapkan kebijakan standarisasi program Diklat Aparatur. Proses standarisasi ini meliputi keseluruhan aspek penyelenggaraan Diklat, mulai dari aspek kurikulum dengan berbagai komponennya sampai dengan pengadministrasian penyelenggaraannya.

Untuk mengetahui sejauhmana standarisasi Diklat ini dilaksanakan maka diperlukan kegiatan evaluasi. Kegiatan Evaluasi merupakan salah satu tahapan dalam proses manajemen Diklat. Menurut Purwanto dan Suparman (Rahmat Suparma, 2008) evaluasi merupakan salah satu mata rantai dalam sistem Diklat yang bisa dilaksanakan dari awal proses perencanaan, proses pelaksanaan, pada akhir penyelenggaraan Diklat sampai dengan setelah peserta Diklat itu berada di tempat kerjanya. Sebagai suatu tahapan dalam pengelolaan program Diklat, peran evaluasi amat menentukan karena evaluasi menjadi alat bagi pemimpin apakah Diklat itu sudah mencapai tujuan atau tidak. Basuki dan Hermansjah (2006) 
berpendapat bahwa evaluasi sebagai tahapan akhir dari suatu proses diklat dimaksudkan untuk mengetahui sejauhmana tingkat efektivitas atas keberhasilan suatu program Diklat meningkatkan kompetensi Pegawai Negeri Sipil dalam melaksanakan tugas jabatannya. Evaluasi sendiri bertujuan untuk mengumpulkan, menganalisis, dan menyajikan informasi yang bermanfaat mengenai objek evaluasi, menilainya dengan membandingkannya dengan indikator dan hasilnya dipergunakan untuk mengambil keputusan mengenai objek evaluasi, (Akbar,MF, 2016). Harapan bagi lembaga Diklat aparatur di Provinsi Gorontalo yang sejak terbentuknya tahun 2000 melalui Badan Kepegawaian dan Pengembangan Aparatur Daerah (BKPAD) untuk menjamin penyelenggaraan Diklat aparatur yang berkualitas. Evaluasi penyelenggaraan Diklat aparatur dapat menggunakan berbagai model yang dikemukakan oleh para ahli antara lain model reaction level dari Kickpatrick. Evaluasi ini bertujuan untuk mengukur reaksi peserta terhadap program pelatihan. Evaluasi ini dilakukan untuk menjawab pertanyaan apakah peserta puas dan menyukai program Diklat yang mereka ikuti, apakah peserta diklat merasa program diklat yang mereka ikuti berguna bagi mereka. Evaluasi model reaction level ini berfokus pada persepsi peserta terhadap program Diklat beserta tingkat efektifitasnya.

Provinsi Gorontalo melalui Badan Kepegawaian, Pendidikan dan Pelatihan Aparatur Daerah (BKPPD) telah melaksanakan berbagai Pendidikan Pelatihan (Diklat) baik itu Diklat tehnis maupun fungsional. Berbagai Diklat yang dilaksanakan ini dipandang penting untuk dilakukan evaluasi dengan menggunakan model reaction level sebagai upaya untuk mengetahui bagaimana persepsi peserta Copyright (c) 2018, Publik : (Jurnal Ilmu Administrasi), ISSN: 2301-573X (Print), ISSN: 2581-2084 (Online) terhadap program Diklat yang selama ini dilaksanakan. Kenyataan menunjukkan bahwa upaya untuk melakukan evaluasi seperti ini belum secara optimal dilakukan oleh BKPPD Provinsi Gorontalo maupun oleh pihak lain baik secara perorangan maupun secara institusional.

\section{METODE PENELITIAN}

Penelitian ini bertujuan untuk mendapatkan gambaran tentang evaluasi penyelengaaraan Pendidikan dan Pelatihan Kepemimpinan Tingkat III (Diklat PIM III) angkatan III Provinsi Gorontalo, menggunakan model reaction level dari Kickpatrick. Jenis penelitian deskriptif kualitatif. Data dikumpulkan menggunakan instrumen angket. Subjek dalam penelitian ini adalah peserta Diklat PIM III angkatan III Provinsi Gorontalo tahun 2015 berjumlah 30 orang.

Instrumen penelitian menggunakan angket yang disusun berdasarkan komponen yang diteliti yakni reaksi peserta terhadap penyelenggaraan Diklat yang diikutinya sehingga dapat diketahui tingkat kepuasaan peserta Diklat. Tingkat kepuasaan disusun dengan mengadaptasi dari hasil kajian teori yang dilakukan penulis yang mencakup aspek-aspek sebagai berikut :

1. Materi, dengan indikator :
a. Sistematika penyajian materi
b. Kejelasan/kemudahan materi untuk dipahami
c. Kontribusi materi dalam peningkatan pengetahuan
d. Manfaat untuk pekerjaan
e. Kesesuaian materi dengan tujuan pelatihan

2. Penyelenggaraan, dengan indikator

a. Kesesuaian pemberian materi dengan jadwal yang telah ditetapkan

b. Kesesuaian isi materi dengan waktu yang tersedia 
c. Ketepatan waktu dalam pelaksanaan pelatihan

d. Kesediaan panitia dalam membantu proses pelatihan

3. Sarana, dengan indikator :

a. Kualitas audio visual atau alat peraga

b. Konsumsi

c. Bahan pelatihan

d. Ruangan (luas, meja/kursi, cahaya, sirkulasi udara)

e. Asrama (luas dan fasilitasnya)

4. Kemampuan widyaiswara, dengan indikator

a. Penguasaan materi

b. Tehnik penyampaian

c. Cara menjawab pertanyaan

d. ,Bahasa yang digunakan

e. Gerakan tubuh (gesture) dan mimik muka

f. Intonasi dan kecepatan berbicara

Tehnik dari kickpatrick sebagai berikut :

Total nilai dari seluruh responden untuk item ke-1

Bobot item ke- 1

Nilai tertinggi pada skala pengukuran $\mathrm{x}$ Jumlah respon x 100\%

Tabel 1. Kriteria Reaction LeveL

\begin{tabular}{cl}
\hline Range & \multicolumn{1}{c}{ Interpretasi } \\
\hline $50 \%$ & Peserta menunjukkan reaksi \\
& kurang baik terhadap pelatihan \\
$50 \%-$ & Peserta menunjukkan reaksi \\
$60 \%$ & yang lebih baik terhadap \\
& pelatihan \\
$61 \%-$ & Peserta menunjukkan reaksi \\
$80 \%$ & yang positif karena menyadari \\
& memperoleh masukan yang \\
& berguna selama pelatihan \\
$81 \%-$ & Peserta menunjukkan reaksi \\
$100 \%$ & positif yang tinggi \\
\hline
\end{tabular}

Format angket yang digunakan untuk mengukur tingkat kepuasan peserta Diklat adalalah sebagai berikut :

Tabel 2. Format Angket

\begin{tabular}{|c|c|c|c|c|c|}
\hline \multirow[b]{2}{*}{ N0. } & \multirow[b]{2}{*}{ Pertanyaan } & \multicolumn{4}{|c|}{ Tingkat Kepuasaan } \\
\hline & & $\begin{array}{l}4 \\
\text { (sangat } \\
\text { puas) }\end{array}$ & $\begin{array}{l}3 \\
\text { (puas) } \\
\end{array}$ & $\begin{array}{l}2 \\
\text { (cukup } \\
\text { puas) }\end{array}$ & $\begin{array}{l}1 \\
\text { (kurang } \\
\text { puas) }\end{array}$ \\
\hline $\begin{array}{l}1 . \\
2 .\end{array}$ & $\ldots$ & & & & \\
\hline 3. & Dst & & & & \\
\hline
\end{tabular}

\section{HASIL DAN PEMBAHASAN}

Dalam bagian ini akan dijelaskan bagaimana hasil yang diperoleh dari hasil penelitian yang berkait dengan penggunaan model evaluasi Reaction Level dan kickpatrick. Kegiatan penelitian diawali dengan menyebarkan angket kepada 30 respon peserta Diklat Kepemimpinan Tingkat III angkatan III Provinsi Gorontalo, peneliti lakukan setelah peserta selesai melaksanakan ujian seminar laporan laboratorium (Breakthrough II). Setelah responden mengisi angket dan menyerahkan kepada peneliti, peneliti melakukan tabulasi dan analisis data dengan menggunakan rumus pembobotan dari kickpatrick sebagai berikut :

Total nilai dari seluruh responden untuk item ke-1

\section{Bobot item ke- 1}

Nilai tertinggi pada skala pengukuran $\mathrm{x}$ Jumlah respon x 100\%

Hasil tabulasi dan analisis data sebagaimana tebel 3 Berikut : 
Tabel 1. 3. Tabulasi dan Analisis Data

\begin{tabular}{|c|c|c|c|c|c|c|c|c|c|c|c|c|c|}
\hline \multirow{3}{*}{ No } & \multirow{3}{*}{ ITEM PERNYATAAN } & \multicolumn{9}{|c|}{ JAWABAN } & & \multirow{3}{*}{$-\mathrm{JLH}$} & \multirow{3}{*}{$\begin{array}{l}\text { BOBOT } \\
\text { ITEM } \\
(\%)\end{array}$} \\
\hline & & \multicolumn{2}{|r|}{4} & \multicolumn{2}{|c|}{3} & \multicolumn{3}{|c|}{2} & \multicolumn{2}{|r|}{1} & & & \\
\hline & & jlh & $\begin{array}{l}\text { total } \\
\text { nilai }\end{array}$ & jlh & $\begin{array}{l}\text { total } \\
\text { nilai }\end{array}$ & jlh & $\begin{array}{l}\text { tot: } \\
\text { nila }\end{array}$ & & jlh & $\begin{array}{l}\text { total } \\
\text { nilai }\end{array}$ & & & \\
\hline 1 & $\begin{array}{l}\text { KOMPONEN MATERI } \\
\text { Sistematika penyajian } \\
\text { materi }\end{array}$ & 14 & 56 & 14 & 42 & 2 & 4 & & - & - & & 102 & 85 \\
\hline 2 & $\begin{array}{l}\text { Kejelasan/kemudahan } \\
\text { materi untuk dipahami }\end{array}$ & 14 & 56 & 14 & 42 & 2 & 4 & & - & - & & 102 & 85 \\
\hline 3 & $\begin{array}{l}\text { Kontribusi materi dalam } \\
\text { peningkatan pengetahuan }\end{array}$ & 13 & 52 & 14 & 42 & 3 & 6 & & - & - & & 100 & 83 \\
\hline 4 & Manfaat dalam pekerjaan & 12 & 48 & 16 & 48 & 2 & 4 & & & - & & 100 & 83 \\
\hline \multirow[t]{3}{*}{5} & $\begin{array}{l}\text { Kesesuaian materi dengan } \\
\text { tujuan pelatihan }\end{array}$ & 11 & 44 & 17 & 51 & 2 & 4 & & - & - & & 99 & 82 \\
\hline & JUMLAH & & & & & & & & & & & & 83.60 \\
\hline & $\begin{array}{l}\text { KOMPONEN } \\
\text { PENYELENGGARAAN }\end{array}$ & & & & & & & & & & & & \\
\hline \multirow[t]{2}{*}{6.} & $\begin{array}{l}\text { Kesesuaian pemberian } \\
\text { materi dengan jadwal } \\
\text { pelatihan }\end{array}$ & 11 & 44 & 16 & 48 & 3 & 6 & & & & & 98 & 82 \\
\hline & & 11 & 44 & 14 & 42 & 5 & 10 & & & & & 96 & 80 \\
\hline 7 & $\begin{array}{l}\text { Kesesuaian isi } \\
\text { dengan materi } \\
\text { tersedia }\end{array}$ & & & & & & & & & & & & \\
\hline 8 & $\begin{array}{l}\text { Ketepatan waktu dalam } \\
\text { pelaksanaan pelatihan }\end{array}$ & 13 & 52 & 15 & 45 & 2 & 4 & & - & - & & 101 & 84 \\
\hline \multirow[t]{2}{*}{9} & $\begin{array}{l}\text { Kesediaan panitia dalam } \\
\text { membantu peserta } \\
\text { pelatihan }\end{array}$ & 13 & 52 & 12 & 36 & 3 & 6 & & 2 & 2 & & 96 & 80 \\
\hline & $\begin{array}{l}\text { JUMLAH } \\
\text { KOMPONEN SARANA }\end{array}$ & & & & & & & & & & & & 81.50 \\
\hline 10. & $\begin{array}{l}\text { Kualitas } \\
\text { visual/media } \\
\text { pembelajaran }\end{array}$ & 10 & 44 & 15 & 45 & 3 & 6 & & 2 & 2 & & 97 & 81 \\
\hline 11. & Konsumsi & 8 & 32 & 18 & 54 & 2 & 4 & & 2 & 2 & & 92 & 77 \\
\hline 12. & Bahan pelatihan & 8 & 32 & 17 & 51 & 2 & 4 & & 3 & 3 & & 90 & 75 \\
\hline 13 & $\begin{array}{l}\text { Ruangan (luas, meja, } \\
\text { kursi, cahaya, sirkulasi } \\
\text { udara }\end{array}$ & 8 & 32 & 14 & 42 & 5 & 10 & & 3 & 3 & & 87 & 73 \\
\hline \multirow[t]{4}{*}{14} & $\begin{array}{l}\text { Asrama/penginapan (luas } \\
\text { dan fasilitasnya) }\end{array}$ & 4 & 16 & 8 & 24 & 8 & 16 & & 10 & 10 & & 66 & 55 \\
\hline & KOMPONEN & & & & & & & & & & & & 72.20 \\
\hline & KEMAMPUAN & & & & & & & & & & & & \\
\hline & TENAGA PENGAJAR & & & & & & & & & & & & \\
\hline 15 & Penguasaan materi & 15 & 60 & 10 & 30 & & 5 & 10 & & - & - & 100 & 83 \\
\hline 16 & Tehnik penyampaian & 15 & 60 & 13 & 39 & & 1 & 2 & & 1 & 1 & 102 & 85 \\
\hline 17 & $\begin{array}{l}\text { Cara menjawab } \\
\text { pertanyaan }\end{array}$ & 14 & 56 & 13 & 39 & & 3 & 6 & & - & - & 101 & 84 \\
\hline 18 & Bahasa yang digunakan & 15 & 60 & 15 & 45 & & - & - & & - & - & 105 & 88 \\
\hline 19 & $\begin{array}{l}\text { Gesture (gerakan tubuh) } \\
\text { dan mimik muka }\end{array}$ & 13 & 52 & 17 & 51 & & - & - & & - & - & 103 & 86 \\
\hline \multirow[t]{2}{*}{20} & $\begin{array}{l}\text { Intonasi dan kecepatan } \\
\text { berbicara }\end{array}$ & 11 & 44 & 18 & 54 & & 1 & 2 & & - & - & 100 & \\
\hline & JUMLAH & & & & & & & & & & & & 84.83 \\
\hline
\end{tabular}

Sumber : Olahan Data Primer 
Untuk memperoleh informasi bagaimana persepsi peserta Diklat terhadap komponen-komponen di atas maka hasil bobot setiap item dikonfersi kedalam tabel kriteria reaction level sebagaimana tabel berikut.

Tabel 4 Kriteria Reaction Level

\begin{tabular}{cl}
\hline Range & \multicolumn{1}{c}{ Interpretasi } \\
\hline $50 \%$ & $\begin{array}{l}\text { Peserta menunjukkan reaksi } \\
\text { kurang baik terhadap } \\
\text { pelatihan }\end{array}$ \\
$50 \%-$ & Peserta menunjukkan reaksi \\
$60 \%$ & yang lebih baik terhadap \\
& pelatihan \\
$61 \%-$ & Peserta menunjukkan reaksi \\
$80 \%$ & yang positif karena \\
& $\begin{array}{l}\text { menyadari memperoleh } \\
\text { masukan yang berguna }\end{array}$ \\
& selama pelatihan \\
$81 \%-$ & $\begin{array}{l}\text { Peserta menunjukkan reaksi } \\
\text { positif yang tinggi }\end{array}$ \\
\hline
\end{tabular}

Memperhatikan hasil konfersi tabel 3 dan tabel 4 hasil penelitian ini menunjukkan bahwa :

1. Peserta menunjukkan reaksi positif yang tinggi terhadap pelatihan berkaitan dengan sebagian besar komponen pelatihan dengan range nilai $81 \%-100$ $\%$ meliputi :

Komponen materi :

a. Sistematika penyajian materi

b. Kejelasan/kemudahan materi untuk dipahami

c. Kontribusi materi dalam peningkatan pengetahuan

d. Manfaat dalam pekerjaan

e. Kesesuaian materi dengan tujuan pelatihan

Komponen Penyelenggaraan :

a. Kesesuaian pemberian materi dengan jadwal pelatihan

b. Ketepatan waktu dalam pelaksanaan pelatihan
Komponen Sarana Prasarana

a. Kualitas audio visual/media pembelajaran

Komponen Tenaga Pengajar

a. Penguasaan materi

b. Tehnik penyampaian

c. Cara menjawab pertanyaan

d. Bahasa yang digunakan

e. Gesture dan mimik muka

f. Intonasi dan kecepatan berbicara

2. Peserta menunjukkan reaksi yang positif karena menyadari memperoleh masukan yang berguna selama pelatihan dengan range nilai $61 \%-80 \%$, meliputi :

Komponen Penyelenggaraan

a. Kesesuaian isi materi dengan waktu yang tersedia

b. Kesediaan panitia dalam membantu peserta pelatihan

Komponen Sarana

a. Konsumsi

b. Bahan pelatihan

c. Ruangan (luas, meja kursi, cahaya, sirkulasiudara)

3. Peserta menunjukkan reaksi yang lebih baik terhadap pelatihan dengan range nilai 50\% - 60\% meliputi komponen asrama/penginapan (luas dan fasilitasnya)

4. Tidak ada peserta yang menunjukkan reaksi kurang baik terhadap pelatihan dengan range nilai dibawah $50 \%$

\section{PENUTUP}

Kesimpulan

Berdasarkan hasil penelitian yang telah diuraikan di atas, maka dapat disimpulkan 1) Peserta menunjukkan reaksi positif yang tinggi terhadap pelatihan berkaitan dengan sebagian besar komponen pelatihan, 2) Peserta menunjukkan reaksi yang positif karena menyadari memperoleh masukan yang berguna selama pelatihan, 3) Peserta 
menunjukkan reaksi yang lebih baik terhadap pelatihan meliputi komponen asrama/penginapan (luas dan fasilitasnya), 4) Tidak ada peserta yang menunjukkan reaksi kurang baik terhadap pelatihan Saran

Sebaiknya kegiatan penyelenggaran pendidikan pelatihan untuk tingkat III dan II di Provinsi Gorontalo hendaknya dapat terus dilaksanakan karena membawa hasil yang positif bagi para peserta yang mengikutinya baik dari segi sisi afektif dan kognitifnya, untuk ke depan model pelatihannya dapat lebih dikembangkan lagi.

\section{DAFTAR PUSTAKA}

Abdulhak I, (2000). Metodelogi pembelajaran orang dewasa, Bandung : Andira

Akbar,MF. (2016). Evaluasi Kebijakan Program Pemberian Dana Bantuan Operasional Sekolah. JAKPP UNHAS. 2(1),47-64

Anwar (2006). Pendidikan Kecakapan Hidup.Bandung : Alfabeta

AR Syamsudin dan S. Damaianti V (2007). Metode Penelitian Pendidikan Bahasa. Bandung : PT Remaja Rosda Karya

Arikunto, S (2002). Prosedur Penelitian. Jakarta : Rineke Cipta

Basuki M, Hermansjah. Evaluasi Purna Diklat. Modul Diklat Kewidyaiswaraan berjenjang tingkat Madya. Jakarta ; LAN RI

Budi Prawira Triton (2006), SPSS 13.0 Terapan, riset statistik Parametrik, Jogyakarta : CV. Andi Offset

Bungin, B. (2003). Penelitian Kualitatif. Jakarta : Kencana

Danim, S (2000). Menjadi Peneliti Kualitatif. Bandung : Pustaka Setia

Effendy Nasri, Purwastuti. Rancangan Penelitian Ilmiah.Modul Diklat Kewidyaiswaraan berjenjang tingkat Madya. Jakarta : LAN RI:

Bumi Aksara

Hariyati, M (2007), Model dan teknik penilaian pada Tingkat Satuan Pendidikan, Jakarta ; Tim Gaung Persada Press

LAN RI, (2008). .Strategi Pembinaan dan Pemberdayaan dalam rangka peningkatan Kualitas Diklat Aparatur.Jakarta ; LAN RI (2015). Peraturan Kepala Lembaga Administrasi Negara (LAN) RI nomor 19 tahun 2015 tentang Pedoman Penyelenggaraan Pendidikan dan Pelatihan Kepemimpinan Tingkat III. LAN RI Firdaus Fery. (2013). Bahan Ajar Rancangan Penelitian Ilmiah. Tidak diterbitkan. LAN-RI

Moleong, L.J, (2008). Metodologi Penelitian Kualitatif .Bandung : Rosda

Sadulloh, U (1994), Pengantar Filsafat Pendidikan.Bandung : Media Iptek

Sugiyanto, Purnomo Bambang (2006), Metode Penelitian Ilmiah Kediklatan. Modul Diklat Kewidyaiswaraan berjenjang tingkat Madya.Jakarta : LAN RI

Sukmadinata, S.N (2004). Kurikulum dan Pembelajaran Kompotensi. Bandung : Yayasan Kusuma Karya (2005). Metode Penelitian Pendidikan. Bandung : PT Remaja Rosda Karya

Suryabrata, S (2003), Metodelogi Penelitian. Jakarta ; Raja Grafindo Persada 